\title{
Liquid-Liquid Equilibrium Data for the Ionic Liquid N-Ethyl-Pyridinium Bromide with Several Sodium Salts and Potassium Salts
}

\author{
Yuliang Li, Xiaojia Lu, Jing Hao, and Changquan Chen \\ School of Environmental Science and Engineering, Chang'an University, Xian 710064, China \\ Correspondence should be addressed to Yuliang Li; yulianglee@hotmail.com
}

Received 7 June 2013; Revised 1 September 2013; Accepted 13 September 2013

Academic Editor: Elena Gomez

Copyright (C) 2013 Yuliang Li et al. This is an open access article distributed under the Creative Commons Attribution License, which permits unrestricted use, distribution, and reproduction in any medium, provided the original work is properly cited.

\begin{abstract}
The liquid-liquid equilibrium (LLE) data for systems containing $\mathrm{N}$-ethyl-pyridinium bromide ([EPy] Br), salt $\left(\mathrm{Na}_{2} \mathrm{HPO}_{4}, \mathrm{~K}_{2} \mathrm{HPO}_{4}\right.$, $\mathrm{K}_{2} \mathrm{SO}_{4}, \mathrm{C}_{4} \mathrm{O}_{6} \mathrm{H}_{4} \mathrm{KNa}$ ), and water have been measured experimentally at $T=298.15 \mathrm{~K}$ and the formations of these four aqueous two-phase systems (ATPSs) have been discussed. Also, the effective excluded volume (EEV) values obtained from the binodal models for the four systems were determined and the salting-out abilities of different salts follow the order of $\mathrm{K}_{2} \mathrm{SO}_{4}>\mathrm{K}_{2} \mathrm{HPO}_{4}>$ $\mathrm{Na}_{2} \mathrm{HPO}_{4}>\mathrm{C}_{4} \mathrm{O}_{6} \mathrm{H}_{4} \mathrm{KNa}$. The solubility data were correlated by the Merchuk and other equations while the tie-line data by the Othmer-Tobias, Bancroft, two-parameter, and Setschenow-type equations. The correlation coefficients evidenced that experimental data fitted well to all these equations. These four salts were proved successfully to form ATPSs with N-ethyl-pyridinium bromide, making a significant contribution to the further study of this kind of ATPS.
\end{abstract}

\section{Introduction}

Aqueous two-phase systems (ATPSs) [1] extraction, an economical and efficient technique for separation, extraction, and purification, have found wide application in comprehensive separation, concentration, and fractionation of biological solutes and particles such as cells and proteins $[2,3]$ for the past few years. An ATPS is essentially a mixture that exists in two phases and is usually formed by two high polymers, a high polymer and a salt, or a hydrophilic organic solvent and a salt [4]. Compared with traditional organic solvent extractions, ATPSs are more effective and can be carried out under mild processing conditions [5].

In recent years, a new type of ATPS based on ionic liquids (ILs) has been investigated, the ILATPS. The ILs are entirely composed of organic cation and organic or inorganic anion, which hold attention because of their chemical and physical properties such as a good thermal, chemical, and electrochemical stability, negligible volatility, a high ionic conductivity, and tenability [6, 7]. Thus, ILATPSs, combining both the advantages of traditional ATPSs and the aforementioned benefits of ILs, have been successfully used in the separation, concentration, and purification of proteins [8], heavy metal ions [9], and small organic molecules [10]. ILATPSs have also been applied to extract antibiotics, such as penicillin G [11] and roxithromycin [12].

Consequently, further work is necessary for the development, optimization, and scale-up of extraction process using ILATPSs. Recently, an aqueous biphasic system (ABS) containing 1-butyl-3-methylimidazolium tetrafluoroborate $\left(\left[\mathrm{C}_{4} \mathrm{mim}\right] \mathrm{BF}_{4}\right)+$ saccharides + water $[13,14]$ has been reported in the literature. In addition, ATPSs composed of $\left[\mathrm{C}_{n} \operatorname{mim}\right] \mathrm{X}(\mathrm{X}=\mathrm{Br}$ and $\mathrm{Cl})+$ salts $\left(\mathrm{KOH}, \mathrm{K}_{2} \mathrm{HPO}_{4}, \mathrm{KH}_{2} \mathrm{PO}_{4}\right.$, $\mathrm{K}_{2} \mathrm{CO}_{3}, \mathrm{~K}_{3} \mathrm{PO}_{4}, \mathrm{~K}_{3} \mathrm{C}_{6} \mathrm{H}_{5} \mathrm{O}_{7}$ and sucrose) [13, 15-18] and [Bmim] $\mathrm{BF}_{4}+$ salts $\left(\mathrm{Na}_{3} \mathrm{PO}_{4}, \mathrm{Na}_{2} \mathrm{CO}_{3}, \mathrm{Na}_{2} \mathrm{SO}_{4}, \mathrm{Na}_{2} \mathrm{SO}_{3}\right.$, $\left(\mathrm{NH}_{4}\right)_{2} \mathrm{SO}_{4}, \mathrm{NaH}_{2} \mathrm{PO}_{4}, \mathrm{NaCl}, \mathrm{Na}_{3} \mathrm{C}_{6} \mathrm{H}_{5} \mathrm{O}_{7}, \mathrm{Na}_{2} \mathrm{C}_{4} \mathrm{H}_{4} \mathrm{O}_{6}$, $\mathrm{NaC}_{2} \mathrm{H}_{3} \mathrm{O}_{2}$, and $\left.\left(\mathrm{NH}_{4}\right)_{3} \mathrm{C}_{6} \mathrm{H}_{5} \mathrm{O}_{7}\right)$ [19-22] also have been reported. For ATPSs containing pyridinium-based ionic liquids, there are 4-methyl-N-butyl pyridinium tetrafluoroborate + cyclohexane [23]. Furthermore, Bridges et al. described the phase diagrams for imidazolium-, pyridium-, and quaternary ammonium- and phosphonium-based chloride salts (all chaotropic salts) salted out by $\mathrm{K}_{3} \mathrm{PO}_{4}, \mathrm{~K}_{2} \mathrm{HPO}_{4}, \mathrm{~K}_{2} \mathrm{CO}_{3}$, 
$\mathrm{KOH}$, and $\left(\mathrm{NH}_{4}\right)_{2} \mathrm{SO}_{4}$ (all kosmotropic salts) [24]. Phase diagrams of ATPS composed of $\mathrm{Mpy} \mathrm{CH}_{3} \mathrm{SO}_{4}$ and $\mathrm{Na}_{2} \mathrm{CO}_{3}$ have also been experimentally ascertained at $T=298.15 \mathrm{~K}$ [25] and the effects of the cation core such as methylimidazolium, methylpyridinium, methylpyrrolidinium and methylpiperidinium, the length of the alkyl side chain, and the positional isomerism on ATPS formation ability of chloride-based ionic liquids such as $\left[1-\mathrm{C}_{4}-2-\mathrm{C}_{1} \mathrm{py}\right] \mathrm{Cl},\left[1-\mathrm{C}_{4}-3-\mathrm{C}_{1} \mathrm{py}\right] \mathrm{Cl},\left[1-\mathrm{C}_{4}-4-\right.$ $\mathrm{C}_{1}$ py] $\mathrm{Cl}$ have been investigated [26].

However, to our knowledge, the experimental work devoted to ILATPSs is far from enough. Compared to the existing imidazolium-based ionic liquids, pyridine-based ionic liquids provide lower cost, lower vapor pressure, better thermal, and chemical stability and are less polluting. An ATPS formed from an ionic liquid which is water soluble at room temperature, $[\mathrm{BPy}] \mathrm{BF}_{4}$ (nitrogen-butyl pyridine tetrafluoroborate) and a phase-forming salt $\left(\mathrm{NH}_{4}\right)_{2} \mathrm{SO}_{4}$ was studied for the extraction and separation of rutin [27]. The ATPS formed by the [EPy] Br and $\mathrm{K}_{2} \mathrm{HPO}_{4}$ for extracting and separating chloramphenicol (CAP) in eggs has also been reported [28]. However, studies regarding this type of ILATPSs are insufficient and require further development.

In this work, phase diagrams and liquid-liquid equilibrium (LLE) data for the [EPy] Br and four kosmotropic salts $\left(\mathrm{Na}_{2} \mathrm{HPO}_{4}, \mathrm{~K}_{2} \mathrm{HPO}_{4}, \mathrm{~K}_{2} \mathrm{SO}_{4}, \mathrm{C}_{4} \mathrm{O}_{6} \mathrm{H}_{4} \mathrm{KNa}\right)$ have been investigated. The solubility curves were fitted to three nonlinear equations, and the tie-lines were described using the OthmerTobias, Bancroft, and Setschenow-type equations and a twoparameter equation. Moreover, the effective excluded volume (EEV) values obtained from the binodal models for the four systems were determined, and the effect of salts on solubility curves and tie-lines were discussed. The as-obtained results are necessary for the design and optimization of extraction processes as well as the development of both thermodynamic and mass transfer models of ILATPSs.

\section{Experimental Section}

2.1. Materials. The $[\mathrm{EP}] \mathrm{Br}$ was purchased from Chengjie Chemical Co., Ltd. (Shanghai, China) with a quoted purity of a mass fraction above 0.99 and was dried under high vacuum at $343.15 \mathrm{~K}$ using a semi-microdistiller with slow heating to remove impurities, mainly water. To prevent contact with the ambient air, the IL was kept in a sealed vessel and placed in refrigerator. The $\mathrm{Na}_{2} \mathrm{HPO}_{4} \cdot 12 \mathrm{H}_{2} \mathrm{O}, \mathrm{K}_{2} \mathrm{HPO}_{4} \cdot 3 \mathrm{H}_{2} \mathrm{O}, \mathrm{K}_{2} \mathrm{SO}_{4}$ and $\mathrm{C}_{4} \mathrm{O}_{6} \mathrm{H}_{4} \mathrm{KNa} \cdot 4 \mathrm{H}_{2} \mathrm{O}$ were analytical grade reagents which were purchased from the Guanghua Chemical Factory Co., Ltd. (Guangdong, China). Double-distilled deionized water was also used in the experiments.

2.2. Experimental Procedure. The solubility curves were determined using the cloud point method. First, an IL solution of known mass fraction was added into a vessel, and the salt solution of known mass fraction was added dropwise until the mixture became cloudy. The composition of the mixture was calculated and the water content of the ionic liquid was calculated into the water mass fraction in the experiment mass balance. Then water was added dropwise until the mixture became clear. The procedure was repeated to obtain all the points on the solubility curves until there was little precipitation at the bottom of the vessel. The vessel was placed in a DC-2008 water thermostat throughout the process, so that the temperature of the system could be kept constant (at $T=298.15 \mathrm{~K}$ ). The temperature was controlled to within $\pm 0.05 \mathrm{~K}$. An analytical balance (model BS $124 \mathrm{~S}$, Beijing Sartorius Instrument Co., China) with a precision of $\pm 1.0 \times 10^{-7} \mathrm{~kg}$ was used to measure the composition of the mixture at each point.

To determine the tie-lines, a series of ATPSs formed from three known compositions (including salt and water) were placed in a temperature-controlled bath. The system was held for at least $24 \mathrm{~h}$ to allow the formation of two phases. Both the upper and the lower phases were sampled for analysis. The concentrations of the salts in the two phases were determined via flame photometry. The uncertainty in the mass fractions of the salts was estimated to be \pm 0.001 . The mass fraction of $[\mathrm{EPy}] \mathrm{Br}$ in both the top phase and bottom phase was determined using a UV-vis spectrophotometer (model UV2450, Shimadzu Corporation, Japan) and the uncertainty was determined to be less than $7.5 \%$. A suitable sample of the top phase or bottom phase was removed and placed into a vessel to be mixed with an appropriate quantity of water. The absorbance of the solution was then measured at a wavelength of $211 \mathrm{~nm}$ to obtain the mass fraction of the ionic liquid according to a standard curve.

The tie-line length (TLL), which reflects the differences between composition of top and bottom phase and the slope of the tie-line $(S)$, which reflects the ability of phase formation to ATPS, were also calculated at different compositions, using the following two equations, respectively, [29]:

$$
\begin{gathered}
\text { TLL }=\left[\left(w_{1}^{t}-w_{1}^{b}\right)^{2}+\left(w_{2}^{t}-w_{2}^{b}\right)^{2}\right]^{0.5} \\
S=\left(w_{1}^{t}-w_{1}^{b}\right) /\left(w_{2}^{t}-w_{2}^{b}\right)
\end{gathered}
$$

where $w_{1}{ }^{t}, w_{1}{ }^{b}, w_{2}{ }^{t}$, and $w_{2}{ }^{b}$ represent the equilibrium mass fraction of the [EPy] Br and salt in the top and bottom phases, respectively. The tie-line data are provided in Table 1.

\section{Results and Discussion}

3.1. Solubility Data and Correlation. The solubility data determined at $T=298.15 \mathrm{~K}$ are listed in Table 2 . The data were fitted using the empirical nonlinear expression developed by Merchuk et al. [30] as follows:

$$
w_{1}=a \exp \left(b w_{2}^{0.5}-c w_{2}^{3}\right),
$$

where $w_{1}$ and $w_{2}$ are the mass fractions of the [EPy] Br and the salt, respectively. This expression has been used for the correlation of IL + salt ATPSs [31, 32] and IL + sugars ATPSs [14]. The parameters for this equation were determined from the experimental data obtained by the cloud point method. Coefficients $a, b$, and $c$ obtained from the correlation of the experimental solubility data with the corresponding standard deviations ( $\mathrm{sd})$ and correlation coefficient $\left(R^{2}\right)$ are given in Table 3. 
TABLE 1: Tile-line data for the [EPy] Br (1) + salt (2) + water (3) ATPS at $T=298.15 \mathrm{~K}$.

\begin{tabular}{lcccccrrr}
\hline \multirow{2}{*}{ System } & \multicolumn{2}{c}{ Total system } & \multicolumn{2}{c}{ IL-rich phase } & \multicolumn{2}{c}{ Salt-rich phase } & \multirow{2}{*}{ TLL } & \\
& $100 w_{2}$ & $100 w_{1}$ & $100 w_{2}$ & $100 w_{1}$ & $100 w_{2}$ & $100 w_{1}$ & \\
\hline & 30.98 & 20.46 & 1.75 & 59.45 & 45.09 & 1.63 & 72.26 & -1.33 \\
{$[$ Epy $] \mathrm{Br}+\mathrm{Na}_{2} \mathrm{HPO}_{4}$} & 20.29 & 30.19 & 2.74 & 53.24 & 41.17 & 2.77 & 63.44 & -1.31 \\
& 10.09 & 41.67 & 3.16 & 51.07 & 37.73 & 4.17 & 58.05 & -1.36 \\
\hline \multirow{2}{*}[\mathrm{Epy}]{$\mathrm{Br}+\mathrm{K}_{2} \mathrm{HPO}_{4}$} & 3.00 & 44.00 & 0.42 & 60.27 & 3.90 & 38.33 & 22.21 & -6.32 \\
& 4.44 & 38.00 & 0.20 & 64.80 & 4.74 & 36.11 & 29.05 & -6.31 \\
& 1.77 & 50.00 & 0.65 & 57.07 & 3.32 & 40.23 & 17.05 & -6.30 \\
\hline & 6.15 & 17.00 & 0.24 & 67.93 & 6.45 & 14.45 & 53.84 & -8.62 \\
{$[\mathrm{Epy}] \mathrm{Br}+\mathrm{K}_{2} \mathrm{SO}_{4}$} & 4.83 & 24.00 & 0.42 & 62.20 & 5.36 & 19.42 & 43.06 & -8.66 \\
& 3.63 & 30.00 & 0.79 & 54.37 & 4.11 & 25.86 & 28.70 & -8.57 \\
\hline & 9.77 & 62.95 & 0.30 & 81.03 & 31.62 & 21.24 & 67.50 & -1.91 \\
{$[\mathrm{EPy}] \mathrm{Br}+\mathrm{C}_{4} \mathrm{O}_{6} \mathrm{H}_{4} \mathrm{KNa}$} & 6.99 & 57.11 & 1.80 & 67.59 & 19.21 & 32.48 & 39.19 & -2.02 \\
& 8.32 & 62.16 & 0.52 & 77.83 & 26.59 & 25.45 & 58.51 & -2.01 \\
\hline
\end{tabular}

To obtain a more accurate fit, a nonlinear empirical expression [33] of the following form was proposed to correlate the solubility data

$$
w_{1}=\exp \left(a+b w_{2}^{0.5}+c w_{2}+d w_{2}^{2}\right),
$$

where $w_{1}$ is the mass fraction of the IL, $w_{2}$ is the mass fraction of the salts, and the coefficients $a, b, c$, and $d$ are fitting parameters. These parameters, along with the correlation coefficient $\left(R^{2}\right)$ and standard deviations (sd), are given in Table 4 .

The following equation was also successfully used in this work to correlate the data:

$$
w_{1}=a_{1} \exp \left(-\frac{w_{2}}{b_{1}}\right)+a_{2} \exp \left(-\frac{w_{2}}{b_{2}}\right)+c
$$

where $w_{1}$ and $w_{2}$ are the mass fractions of the IL and salts, respectively. This equation has been extended to fit the results of the ATPSs based on hydrophilic organic solvents [34, 35]. The coefficients $a_{1}, a_{2}, b_{1}, b_{2}$, and $c$ along with the correlation coefficient $\left(R^{2}\right)$ and the standard deviations (sd) are listed in Table 5.

The solubility curves determined at $T=298.15 \mathrm{~K}$ for the [EPy] $\mathrm{Br}(1)+$ salt (2) $\left(\mathrm{Na}_{2} \mathrm{HPO}_{4}, \mathrm{~K}_{2} \mathrm{HPO}_{4}, \mathrm{~K}_{2} \mathrm{SO}_{4}\right.$, $\mathrm{C}_{4} \mathrm{O}_{6} \mathrm{H}_{4} \mathrm{KNa}$ ) + water (3) systems, which provided the minimum concentration required for the formation of these four ATPSs, are plotted in Figure 1, from which it can be observed that an ATPS can be produced by adding an appropriate amount of one salt to an aqueous solution of [EPy]Br. Moreover, one can easily conclude that the phase-separation abilities of the salts follow the order of $\mathrm{K}_{2} \mathrm{SO}_{4}>\mathrm{K}_{2} \mathrm{HPO}_{4}>$ $\mathrm{Na}_{2} \mathrm{HPO}_{4}>\mathrm{C}_{4} \mathrm{O}_{6} \mathrm{H}_{4} \mathrm{KNa}$ by comparing different curves in the phase diagram.

Based on the as-obtained $R^{2}$ and standard deviation values in Tables $3-5$, it can be concluded that (2)-(4) are satisfactory for correlating the solubility curves of the investigated systems. The same levels of satisfactory results were obtained in other ILATPS as well [36]. Furthermore, the Merchuk equation performs best of the three while it possesses only three adjustable parameters.
3.2. Effective Excluded Volume (EEV) and Salting-out Ability. A binodal model based on the statistical geometry method developed by Guan et al. [37] for aqueous polymer systems was applied to correlate the experimental solubility data of ATPSs containing $\mathrm{Na}_{2} \mathrm{HPO}_{4}, \mathrm{~K}_{2} \mathrm{HPO}_{4}, \mathrm{~K}_{2} \mathrm{SO}_{4}$, and $\mathrm{C}_{4} \mathrm{O}_{6} \mathrm{H}_{4} \mathrm{KNa}$ in this paper. The binodal equation can be written as follows:

$$
\begin{gathered}
\ln \left(V_{213}^{*} \frac{w_{2}}{M_{2}}+f_{213}\right)+V_{213}^{*} \frac{w_{1}}{M_{1}}=0 \\
\ln \left(V_{213}^{*} \frac{w_{2}}{M_{2}}\right)+V_{213}^{*} \frac{w_{1}}{M_{1}}=0,
\end{gathered}
$$

where $V_{213}^{*}, f_{213}, M_{1}$, and $M_{2}$ are the scaled EEV of the salts, the volume fraction of the unfilled effective available volume after tightly packing the salt molecules into the network of ionic liquid molecules in the ionic liquid aqueous solutions, and the molar masses of the ionic liquid and salt, respectively. The values of $V_{213}^{*}$ and $f_{213}$ derived from the correlation of the experimental solubility data and the corresponding correlation coefficients $\left(R^{2}\right)$ and standard deviations (sd) are given in Tables 6 and 7 .

The salting-out ability of the salt could be related to the EEV [38-40]. The salt with higher salting-out ability has a larger EEV value at the same temperature. This is because with a increase in EEV, the solubility line moves to the left of the phase diagram and the single-phase area decreases correspondingly, resulting in the decline of salts content forming ILATPS, which means that salting-out ability becomes stronger. The EEV represents the smallest spacing of the individual ionic liquid that will adopt an individual salt, reflecting the compatibility of both components in a system. In this study, the EEVs have been calculated using the binodal model developed by Guan et al. [37]. In the original application, (7) was used to correlate the solubility data of polymer-polymer systems because the two components significantly vary in size. The $f_{213}$ value is so small that it can be neglected without obvious influence. From Table 7, it can be found that the parameter $f_{213}$ was small enough to be neglected for the investigated systems, and the standard 
TABLE 2: Solubility Data for [EPy]Br (1) + salt (2) + water (3) ATPS at $T=298.15 \mathrm{~K}$.

\begin{tabular}{|c|c|c|c|c|c|c|c|c|}
\hline Salt & $100 w_{2}$ & $100 w_{1}$ & $100 w_{2}$ & $100 w_{1}$ & $100 w_{2}$ & $100 w_{1}$ & $100 w_{2}$ & $100 w_{1}$ \\
\hline & 0.39 & 75.96 & 2.65 & 54.63 & 8.37 & 34.17 & 15.96 & 23.49 \\
\hline & 0.53 & 72.39 & 2.67 & 54.30 & 8.50 & 33.98 & 16.05 & 23.39 \\
\hline & 0.63 & 70.30 & 2.68 & 54.47 & 8.61 & 33.74 & 16.20 & 23.13 \\
\hline & 0.68 & 68.79 & 2.71 & 54.15 & 8.71 & 33.60 & 16.30 & 23.00 \\
\hline & 0.69 & 68.13 & 2.72 & 53.74 & 8.84 & 33.38 & 16.70 & 22.53 \\
\hline & 0.78 & 66.87 & 2.73 & 54.33 & 8.95 & 33.21 & 16.84 & 22.25 \\
\hline & 0.80 & 66.11 & 2.74 & 53.91 & 9.05 & 33.03 & 16.95 & 22.13 \\
\hline & 0.95 & 65.96 & 2.75 & 53.59 & 9.17 & 32.83 & 17.05 & 22.01 \\
\hline & 0.96 & 66.23 & 2.76 & 53.76 & 9.28 & 32.66 & 17.15 & 21.91 \\
\hline & 0.99 & 65.67 & 2.79 & 53.44 & 9.41 & 32.39 & 17.36 & 21.71 \\
\hline & 1.02 & 65.43 & 2.80 & 53.61 & 9.53 & 32.17 & 17.56 & 21.41 \\
\hline & 1.05 & 65.18 & 2.82 & 53.36 & 9.65 & 31.96 & 17.78 & 21.15 \\
\hline & 1.09 & 64.76 & 2.83 & 53.54 & 9.77 & 31.75 & 18.02 & 20.90 \\
\hline & 1.14 & 64.30 & 2.86 & 53.16 & 9.90 & 31.54 & 18.19 & 20.62 \\
\hline & 1.17 & 64.06 & 2.87 & 53.35 & 10.03 & 31.32 & 18.31 & 20.47 \\
\hline & 1.20 & 63.74 & 2.90 & 53.02 & 10.16 & 31.11 & 18.49 & 20.15 \\
\hline & 1.23 & 63.50 & 2.91 & 53.20 & 10.29 & 30.87 & 18.62 & 19.99 \\
\hline & 1.27 & 63.28 & 2.93 & 52.88 & 10.47 & 30.44 & 18.74 & 19.86 \\
\hline & 1.30 & 62.99 & 2.94 & 53.06 & 10.59 & 30.30 & 18.87 & 19.73 \\
\hline & 1.35 & 62.71 & 3.00 & 52.62 & 10.71 & 30.14 & 19.00 & 19.59 \\
\hline & 1.39 & 62.67 & 3.01 & 52.81 & 10.83 & 30.14 & 19.13 & 19.45 \\
\hline & 1.45 & 62.13 & 3.04 & 52.44 & 10.97 & 29.99 & 19.27 & 19.31 \\
\hline & 1.52 & 61.54 & 3.05 & 52.63 & 11.08 & 29.77 & 19.42 & 19.17 \\
\hline & 1.56 & 61.25 & 3.08 & 52.26 & 11.17 & 29.67 & 19.62 & 18.82 \\
\hline & 1.63 & 60.68 & 3.10 & 52.45 & 11.28 & 29.45 & 19.75 & 18.66 \\
\hline & 1.68 & 60.32 & 3.12 & 51.50 & 11.40 & 29.23 & 19.89 & 18.50 \\
\hline & 1.74 & 59.92 & 3.17 & 52.27 & 11.52 & 29.01 & 20.02 & 18.34 \\
\hline & 1.79 & 59.51 & 3.41 & 49.90 & 11.62 & 28.90 & 20.16 & 18.17 \\
\hline & 1.84 & 59.14 & 3.99 & 47.46 & 11.77 & 28.73 & 20.30 & 18.00 \\
\hline & 1.89 & 58.56 & 4.61 & 45.13 & 11.89 & 28.50 & 20.45 & 17.85 \\
\hline & 1.90 & 58.69 & 5.04 & 40.83 & 12.00 & 28.38 & 20.59 & 17.67 \\
\hline \multirow{20}{*}{$\mathrm{Na}_{2} \mathrm{HPO}_{4}$} & 1.92 & 58.35 & 5.15 & 40.62 & 12.11 & 28.20 & 20.89 & 17.32 \\
\hline & 1.93 & 58.48 & 5.16 & 41.91 & 12.24 & 27.96 & 21.20 & 16.98 \\
\hline & 1.96 & 58.12 & 5.29 & 40.81 & 12.35 & 27.83 & 21.52 & 16.62 \\
\hline & 1.97 & 58.25 & 5.37 & 40.83 & 12.49 & 27.59 & 21.85 & 16.22 \\
\hline & 2.00 & 57.95 & 5.45 & 40.51 & 12.63 & 27.35 & 22.19 & 15.84 \\
\hline & 2.01 & 58.09 & 5.48 & 40.33 & 12.74 & 27.23 & 22.54 & 15.43 \\
\hline & 2.04 & 57.71 & 5.52 & 40.41 & 12.88 & 26.96 & 22.90 & 14.99 \\
\hline & 2.05 & 57.85 & 5.60 & 40.15 & 13.00 & 26.82 & 23.25 & 14.56 \\
\hline & 2.09 & 57.46 & 5.75 & 39.45 & 13.13 & 26.69 & 23.62 & 14.10 \\
\hline & 2.10 & 57.60 & 5.77 & 39.01 & 13.28 & 26.40 & 24.00 & 13.67 \\
\hline & 2.14 & 57.20 & 5.85 & 39.26 & 13.41 & 26.25 & 24.46 & 13.23 \\
\hline & 2.15 & 57.35 & 5.95 & 38.89 & 13.57 & 25.97 & 24.88 & 12.78 \\
\hline & 2.19 & 56.87 & 6.10 & 38.85 & 13.73 & 25.72 & 25.29 & 12.31 \\
\hline & 2.20 & 57.02 & 6.22 & 38.67 & 13.83 & 25.70 & 25.75 & 11.83 \\
\hline & 2.24 & 56.69 & 6.32 & 38.40 & 13.93 & 25.68 & 26.49 & 11.01 \\
\hline & 2.25 & 56.84 & 6.43 & 38.18 & 14.04 & 25.62 & 26.85 & 10.76 \\
\hline & 2.28 & 56.26 & 6.56 & 37.72 & 14.21 & 25.61 & 27.10 & 10.48 \\
\hline & 2.29 & 56.41 & 6.66 & 37.41 & 14.35 & 25.40 & 27.46 & 10.20 \\
\hline & 2.33 & 55.80 & 6.77 & 37.22 & 14.42 & 25.31 & 27.99 & 9.64 \\
\hline & 2.34 & 55.95 & 6.87 & 37.19 & 14.49 & 25.26 & 28.62 & 9.06 \\
\hline
\end{tabular}


TABle 2: Continued.

\begin{tabular}{|c|c|c|c|c|c|c|c|c|}
\hline Salt & $100 w_{2}$ & $100 w_{1}$ & $100 w_{2}$ & $100 w_{1}$ & $100 w_{2}$ & $100 w_{1}$ & $100 w_{2}$ & $100 w_{1}$ \\
\hline & 2.36 & 55.84 & 6.99 & 37.00 & 14.60 & 25.01 & 29.31 & 8.52 \\
\hline & 2.37 & 56.00 & 7.10 & 36.69 & 14.72 & 24.97 & 30.02 & 7.93 \\
\hline & 2.40 & 55.89 & 7.21 & 36.50 & 14.80 & 24.88 & 30.97 & 7.34 \\
\hline & 2.41 & 56.05 & 7.33 & 36.15 & 14.87 & 24.78 & 31.78 & 6.69 \\
\hline & 2.45 & 55.62 & 7.43 & 35.91 & 14.95 & 24.69 & 32.63 & 6.01 \\
\hline & 2.46 & 55.78 & 7.54 & 35.81 & 15.08 & 24.45 & 33.14 & 5.68 \\
\hline & 2.51 & 55.36 & 7.63 & 35.74 & 15.20 & 24.40 & 33.66 & 5.35 \\
\hline & 2.52 & 55.53 & 7.73 & 35.55 & 15.29 & 24.34 & 34.39 & 5.05 \\
\hline & 2.56 & 54.95 & 7.82 & 35.45 & 15.38 & 24.25 & 35.15 & 4.71 \\
\hline & 2.57 & 55.12 & 7.94 & 35.10 & 15.50 & 24.01 & 35.90 & 4.39 \\
\hline & 2.61 & 54.59 & 8.03 & 34.87 & 15.58 & 23.90 & 36.81 & 4.02 \\
\hline & 2.62 & 54.76 & 8.14 & 34.65 & 15.68 & 23.80 & 37.75 & 3.57 \\
\hline & 2.64 & 54.46 & 8.27 & 34.41 & 15.77 & 23.69 & 39.04 & 3.17 \\
\hline \multirow{13}{*}{$\mathrm{K}_{2} \mathrm{HPO}_{4}$} & 1.24 & 51.48 & 1.72 & 47.66 & 2.53 & 43.64 & 3.70 & 38.59 \\
\hline & 1.26 & 51.29 & 1.77 & 47.21 & 2.62 & 43.11 & 3.80 & 38.28 \\
\hline & 1.30 & 50.97 & 1.82 & 46.95 & 2.76 & 42.32 & 3.89 & 38.05 \\
\hline & 1.34 & 50.68 & 1.88 & 46.75 & 2.86 & 42.07 & 3.94 & 38.02 \\
\hline & 1.38 & 50.28 & 1.93 & 46.41 & 3.02 & 41.38 & 4.04 & 37.73 \\
\hline & 1.41 & 50.02 & 2.00 & 46.07 & 3.19 & 40.64 & 4.18 & 37.35 \\
\hline & 1.44 & 49.83 & 2.06 & 45.66 & 3.24 & 40.42 & 4.33 & 36.85 \\
\hline & 1.47 & 49.54 & 2.12 & 45.22 & 3.30 & 40.17 & 4.44 & 37.02 \\
\hline & 1.51 & 49.28 & 2.20 & 44.97 & 3.36 & 39.94 & 4.55 & 36.49 \\
\hline & 1.56 & 48.82 & 2.28 & 44.71 & 3.43 & 39.72 & 4.70 & 36.10 \\
\hline & 1.60 & 48.63 & 2.34 & 44.43 & 3.48 & 39.45 & 4.88 & 35.93 \\
\hline & 1.64 & 48.25 & 2.38 & 44.18 & 3.55 & 39.37 & 5.00 & 35.30 \\
\hline & 1.68 & 47.99 & 2.42 & 43.91 & 3.63 & 39.11 & 5.17 & 34.74 \\
\hline \multirow{7}{*}{$\mathrm{K}_{2} \mathrm{SO}_{4}$} & 7.36 & 10.51 & 4.56 & 23.33 & 3.33 & 30.28 & 2.46 & 36.40 \\
\hline & 6.74 & 13.54 & 4.32 & 24.69 & 3.18 & 31.45 & 2.34 & 37.26 \\
\hline & 6.15 & 15.80 & 4.14 & 25.71 & 3.03 & 32.45 & 2.24 & 37.88 \\
\hline & 5.70 & 17.96 & 3.94 & 26.70 & 2.92 & 33.20 & 2.14 & 38.80 \\
\hline & 5.41 & 19.19 & 3.77 & 27.79 & 2.80 & 33.79 & & \\
\hline & 5.18 & 20.37 & 3.63 & 28.73 & 2.68 & 34.89 & & \\
\hline & 4.84 & 21.91 & 3.49 & 29.41 & 2.57 & 35.51 & & \\
\hline \multirow{14}{*}{$\mathrm{C}_{4} \mathrm{O}_{6} \mathrm{H}_{4} \mathrm{KNa}$} & 0.48 & 78.95 & 3.40 & 59.50 & 7.67 & 48.26 & 14.41 & 37.88 \\
\hline & 0.70 & 77.03 & 3.55 & 58.99 & 8.06 & 47.57 & 15.45 & 36.29 \\
\hline & 0.80 & 75.16 & 3.75 & 58.28 & 8.23 & 47.19 & 16.20 & 34.94 \\
\hline & 0.82 & 75.03 & 4.10 & 57.11 & 8.72 & 46.26 & 16.75 & 34.77 \\
\hline & 0.98 & 73.40 & 5.19 & 54.71 & 9.49 & 44.88 & 17.19 & 34.17 \\
\hline & 1.17 & 71.64 & 5.45 & 53.74 & 10.39 & 43.43 & 17.34 & 33.96 \\
\hline & 1.34 & 70.30 & 5.49 & 53.55 & 11.09 & 42.35 & 17.79 & 33.54 \\
\hline & 1.98 & 66.65 & 5.81 & 52.73 & 12.12 & 40.77 & 18.26 & 33.07 \\
\hline & 2.19 & 64.97 & 6.04 & 52.08 & 12.68 & 39.86 & 18.78 & 32.53 \\
\hline & 2.38 & 64.09 & 6.23 & 51.73 & 13.32 & 39.11 & 19.22 & 32.18 \\
\hline & 2.67 & 62.83 & 6.64 & 50.68 & 13.68 & 38.94 & 19.31 & 31.97 \\
\hline & 2.82 & 61.98 & 6.82 & 50.35 & 13.95 & 38.49 & 19.38 & 31.81 \\
\hline & 2.99 & 61.25 & 7.08 & 49.62 & 14.18 & 38.20 & & \\
\hline & 3.21 & 60.31 & 7.28 & 49.23 & 14.27 & 38.27 & & \\
\hline
\end{tabular}


TABLE 3: Parameters of (2) for the [EPy]Br (1) + salt (2) + water (3) ATPS at $T=298.15 \mathrm{~K}$.

\begin{tabular}{|c|c|c|c|c|c|}
\hline System & $a$ & $b$ & $c$ & $R^{2}$ & $\mathrm{sd}^{\mathrm{a}}$ \\
\hline$[\mathrm{EPy}] \mathrm{Br}+\mathrm{Na}_{2} \mathrm{HPO}_{4}$ & 92.2445 & -0.3321 & $1.9677 E-5$ & 0.9978 & 0.84 \\
\hline$[\mathrm{EPy}] \mathrm{Br}+\mathrm{K}_{2} \mathrm{HPO}_{4}$ & 75.9749 & -0.3544 & $-2.5871 E-5$ & 0.9991 & 0.88 \\
\hline$[\mathrm{EPy}] \mathrm{Br}+\mathrm{K}_{2} \mathrm{SO}_{4}$ & 89.4813 & -0.5691 & $1.4900 E-3$ & 0.9997 & 0.12 \\
\hline$[\mathrm{EPy}] \mathrm{Br}+\mathrm{C}_{4} \mathrm{O}_{6} \mathrm{H}_{4} \mathrm{KNa}$ & 91.7650 & -0.2277 & $5.7919 E-6$ & 0.9994 & 0.17 \\
\hline
\end{tabular}

${ }^{\mathrm{a}} \mathrm{sd}=\left(\sum_{i=1}^{N}\left(w_{i}^{\mathrm{cal}}-w_{i}^{\text {exp }}\right)^{2} / N\right)^{0.5}$. Where $w_{i}^{\text {exp }}$ is the experimental mass fraction of IL and $w_{i}^{\text {cal }}$ is the corresponding data calculated using (2). The term " $N$ " represents the number of solubility data.

TABLE 4: Parameters of (3) for the [EPy]Br (1) + salt (2) + water (3) ATPS at $T=298.15 \mathrm{~K}$.

\begin{tabular}{lccccc}
\hline System & $a$ & $b$ & $c$ & $d$ & $R^{2}$ \\
\hline$[\mathrm{EPy}] \mathrm{Br}+\mathrm{Na}_{2} \mathrm{HPO}_{4}$ & 4.5736 & -0.4040 & 0.0271 & -0.0011 & 0.9972 \\
{$[\mathrm{EPy}] \mathrm{Br}+\mathrm{K}_{2} \mathrm{HPO}_{4}$} & 4.7432 & -1.0384 & 0.3074 & -0.0157 & 0.96 \\
{$[\mathrm{EPy}]+\mathrm{K}_{2} \mathrm{SO}_{4}$} & 4.9165 & -1.2750 & 0.3488 & -0.0303 & 0.9992 \\
{$[\mathrm{EPy}] \mathrm{Br}+\mathrm{C}_{4} \mathrm{O}_{6} \mathrm{H}_{4} \mathrm{KNa}$} & 4.5676 & -0.2982 & 0.0246 & $-7.0600 E-4$ & 0.9996 \\
\hline
\end{tabular}

${ }^{\mathrm{a}} \mathrm{sd}=\left(\sum_{i=1}^{N}\left(w_{i}^{\mathrm{cal}}-w_{i}^{\exp }\right)^{2} / N\right)^{0.5}$. Where $w_{i}^{\text {exp }}$ is the experimental mass fraction of IL and $w_{i}^{\text {cal }}$ is the corresponding data calculated using (3). The term " $N$ " represents the number of solubility data.

deviation in (7) differed significantly from that in (6) for the solubility data fitting, rendering (7) unusable.

According to Table 6 , the salting-out ability of the salts at a constant temperature follows the order: $\mathrm{K}_{2} \mathrm{SO}_{4}>$ $\mathrm{K}_{2} \mathrm{HPO}_{4}>\mathrm{Na}_{2} \mathrm{HPO}_{4}>\mathrm{C}_{4} \mathrm{O}_{6} \mathrm{H}_{4} \mathrm{KNa}$, which is in agreement with the phase-separation abilities determined from Figure 1. Apparently, (6) satisfactorily reproduce the solubility curves of the investigated systems. However, when compared to the Merchuk and two other equations, there see a big gap.

Some also insist that salting-out abilities of different salts have something to do with ion hydration free energy $\left(\Delta G_{\text {hyd }}\right)$ [41], the more negative the ions, the stronger their salting-out abilities. $\mathrm{K}_{2} \mathrm{HPO}_{4}$ and $\mathrm{Na}_{2} \mathrm{HPO}_{4}$ share the same anion, the cation radius of cation $\mathrm{K}^{+}$exceeds that of $\mathrm{Na}^{+}$, and $\Delta G_{\text {hyd }}$ of $\mathrm{K}^{+}$and $\mathrm{Na}^{+}$are -295 and $-365 \mathrm{~kJ} \cdot \mathrm{mol}^{-1}$, respectively. In accordance with the ion hydration free energy theory, the salting-out ability of $\mathrm{Na}_{2} \mathrm{HPO}_{4}$ should be stronger than $\mathrm{K}_{2} \mathrm{HPO}_{4}$. However, we found that in our study that although $\Delta G_{\text {hyd }}$ of $\mathrm{K}^{+}$is greater than $\mathrm{Na}^{+}$, the saltingout ability is much higher. Still, the anions promote the formation of ATPSs in the following order: $\mathrm{SO}_{4}{ }^{2-}\left(\Delta G_{\text {hyd }}=\right.$ $\left.-1080 \mathrm{~kJ} \cdot \mathrm{mol}^{-1}\right)>\mathrm{HPO}_{4}^{2-}\left(\Delta G_{\text {hyd }}=-1789 \mathrm{~kJ} \cdot \mathrm{mol}^{-1}\right)$, which also deviates from the ion hydration free energy theory.

3.3. Tie-Line Data and Correlation. The tie-line compositions, tie-line length (TLL), and average slopes $(S)$ determined at $T=298.15 \mathrm{~K}$ are listed in Table 1 and Figures 2 and 3. In this work, the tie-line compositions are closely connected by the Othmer-Tobias equation (6) and Bancroft equation $(7)[42,43]$ as follows:

$$
\begin{aligned}
\left(\frac{1-w_{1}^{t}}{w_{1}^{t}}\right) & =k_{1}\left(\frac{1-w_{2}^{b}}{w_{2}^{b}}\right)^{n} \\
\left(\frac{w_{3}^{b}}{w_{2}^{b}}\right) & =k_{2}\left(\frac{w_{3}^{t}}{w_{1}^{t}}\right)^{r} .
\end{aligned}
$$

In these equations, $w_{1}^{t}$ is the mass fraction of the IL in the top phase; $w_{2}{ }^{t}$ is the mass fraction of the salt in the bottom phase; $w_{3}{ }^{b}$ and $w_{3}{ }^{t}$ are the mass fractions of water in the bottom and top phases, respectively. Recently, (6) and (7) have been successfully verified by other ATPS researchers, indicating that the two equations can accurately correlate the tie-line data of the systems. The plots of $\log [(1-$ $\left.\left.w_{1}^{t}\right) / w_{1}^{t}\right]$ against $\log \left[\left(1-w_{2}^{b}\right) / w_{2}^{b}\right]$ and $\log \left(w_{3}^{b} / w_{2}^{b}\right)$ against $\log \left(w_{3}{ }^{t} / w_{1}^{t}\right)$ shows linear relationships, indicating acceptable consistency of the results. The values of the fit parameters $k_{1}, n, k_{2}$, and $r$, the coefficient values $\left(R^{2}\right)$,and the standard deviations (sd) are listed in Table 8.

For further confirmation, the Setschenow-type equation [44] was used to correlate the tie-line compositions of the $[\mathrm{EPy}] \mathrm{Br}+\mathrm{Na}_{2} \mathrm{HPO}_{4} / \mathrm{K}_{2} \mathrm{HPO}_{4} / \mathrm{K}_{2} \mathrm{SO}_{4} / \mathrm{C}_{4} \mathrm{O}_{6} \mathrm{H}_{4} \mathrm{KNa}$ ATPSs at $T=298.15 \mathrm{~K}$ :

$$
\ln \left(\frac{c_{1}^{t}}{c_{1}^{b}}\right)=k_{\mathrm{IL}}\left(c_{1}^{b}-c_{1}^{t}\right)+k_{s}\left(c_{2}^{b}-c_{2}^{t}\right)
$$

In the above equation, $c_{1}, c_{2}, k_{\mathrm{IL}}$, and $k_{s}$ represent the molality of the IL, the molality of the salt, a parameter relating the activity coefficient of the IL to its concentration, and the salting-out coefficient, respectively. The two superscripts " $t$ " and " $b$ " represent the IL-rich phase and the salt-rich phase, respectively. Assuming that the first term on the right side of this equation is negligible in comparison with the second term, a Setschenow-type equation can be obtained, implying that $k_{\mathrm{IL}} \ll k_{s}$ because the absolute values of $\left(c_{1}^{b}-c_{1}{ }^{t}\right)$ exceed those of $\left(c_{2}^{b}-c_{2}{ }^{t}\right)$. This equation was successfully used for the correlation of tie-line data for the IL + salt ATPSs [42]. The salting-out coefficients, $k_{s}$, with the corresponding intercepts, correlation coefficient $\left(R^{2}\right)$ as well as standard deviations (sd) are all listed in Table 9.

In our study, a correlating equation with two parameters has also been used to determine the tie-line data which can be 
TABLE 5: Parameters of (4) for the [EPy]Br (1) + salt (2) + water (3) ATPS at $T=298.15 \mathrm{~K}$.

\begin{tabular}{|c|c|c|c|c|c|c|c|}
\hline System & $a_{1}$ & $b_{1}$ & $a_{2}$ & $b_{2}$ & $c$ & $R^{2}$ & $\mathrm{sd}^{\mathrm{a}}$ \\
\hline$[\mathrm{EPy}] \mathrm{Br}+\mathrm{Na}_{2} \mathrm{HPO}_{4}$ & 23.3946 & $-3.4874 E 19$ & 61.9954 & 11.0376 & -16.9351 & 0.9859 & 2.14 \\
\hline$[\mathrm{EPy}] \mathrm{Br}+\mathrm{K}_{2} \mathrm{HPO}_{4}$ & 9.4472 & $-8.8659 E 22$ & 32.6463 & 2.7530 & 20.9157 & 0.9968 & 0.27 \\
\hline$[\mathrm{EPy}]+\mathrm{K}_{2} \mathrm{SO}_{4}$ & 9.0913 & $-2.2954 E 19$ & 73.7805 & 7.5619 & -26.0714 & 0.9996 & 0.49 \\
\hline$[\mathrm{EPy}] \mathrm{Br}+\mathrm{C}_{4} \mathrm{O}_{6} \mathrm{H}_{4} \mathrm{KNa}$ & 9.8253 & $-2.8063 E 23$ & 49.0484 & 8.0236 & 19.4759 & 0.9911 & 1.28 \\
\hline
\end{tabular}

${ }^{a} \mathrm{sd}=\left(\sum_{i=1}^{N}\left(w_{i}^{\mathrm{cal}}-w_{i}^{\exp }\right)^{2} / N\right)^{0.5}$. Where $w_{i}^{\exp }$ is the experimental mass fraction of IL and $w_{i}^{\mathrm{cal}}$ is the corresponding data calculated using (4). The term " $N$ " represents the number of solubility data.

TABLE 6: Parameters of (5a) for the [EPy]Br (1) + salt (2) + water (3) ATPS at $T=298.15 \mathrm{~K}$.

\begin{tabular}{lcccc}
\hline System & $V_{213}^{*}$ & $f_{213}$ & $R^{2}$ & $s^{\mathrm{a}}$ \\
\hline$[\mathrm{EPy}] \mathrm{Br}+\mathrm{Na}_{2} \mathrm{HPO}_{4}$ & 5.2183 & 0.2018 & 0.9828 & 0.64 \\
{$[\mathrm{EPy}] \mathrm{Br}+\mathrm{K}_{2} \mathrm{HPO}_{4}$} & 5.6397 & 0.1259 & 0.9824 & 2.39 \\
{$[\mathrm{EPy}] \mathrm{Br}+\mathrm{K}_{2} \mathrm{SO}_{4}$} & 11.4851 & -0.0575 & 0.9814 & 1.10 \\
{$[\mathrm{EPy}] \mathrm{Br}+\mathrm{C}_{4} \mathrm{O}_{6} \mathrm{H}_{4} \mathrm{KNa}$} & 4.7262 & 0.1524 & 0.9730 & 2.26 \\
\hline
\end{tabular}

${ }_{\mathrm{sd}}=\left(\sum_{i=1}^{N}\left(w_{i}^{\mathrm{cal}}-w_{i}^{\exp }\right)^{2} / N\right)^{0.5}$. Where $w_{i}^{\text {exp }}$ is the experimental mass fraction of IL and $w_{i}^{\text {cal }}$ is the corresponding data calculated using (6). The term " $N$ " represents the number of solubility data.

TABLe 7: Parameters of (5b) for the [EPy]Br (1) + salt (2) + water (3) ATPS at $T=298.15 \mathrm{~K}$.

\begin{tabular}{lccc}
\hline System & $V_{213}^{*}$ & $R^{2}$ & $\mathrm{sd}^{\mathrm{a}}$ \\
\hline$[\mathrm{EPy}] \mathrm{Br}+\mathrm{Na}_{2} \mathrm{HPO}_{4}$ & 8.4568 & 0.0758 & 21.75 \\
{$[\mathrm{EPy}] \mathrm{Br}+\mathrm{K}_{2} \mathrm{HPO}_{4}$} & 8.5867 & 0.8820 & 38.25 \\
{$[\mathrm{EPy}] \mathrm{Br}+\mathrm{K}_{2} \mathrm{SO}_{4}$} & 10.2939 & 0.9601 & 2.57 \\
{$[\mathrm{EPy}] \mathrm{Br}+\mathrm{C}_{4} \mathrm{O}_{6} \mathrm{H}_{4} \mathrm{KNa}$} & 7.4313 & 0.1268 & 160.50 \\
\hline
\end{tabular}

${ }^{\mathrm{a}} \mathrm{sd}=\left(\sum_{i=1}^{N}\left(w_{i}^{\mathrm{cal}}-w_{i}^{\exp }\right)^{2} / N\right)^{0.5}$. Where $w_{i}^{\text {exp }}$ is the experimental mass fraction of IL and $w_{i}^{\text {cal }}$ is the corresponding data calculated using (7). The term " $N$ " represents the number of solubility data.

TABLE 8: Parameters of (6) and (7) for the [EPy]Br (1) + salt (2) + water (3) ATPS at $T=298.15 \mathrm{~K}$.

\begin{tabular}{lcccccccc}
\hline System & $k_{1}$ & $n$ & $R_{1}^{2}$ & $\mathrm{sd}_{1}{ }^{\mathrm{a}}$ & $k_{2}$ & $r$ & $R_{2}^{2}$ & $\mathrm{sd}_{2}{ }^{\mathrm{a}}$ \\
\hline$[\mathrm{EPy}] \mathrm{Br}+\mathrm{Na}_{2} \mathrm{HPO}_{4}$ & 0.5605 & 1.1210 & 0.8815 & 2.24 & 1.6422 & 0.8044 & 0.8802 & 0.06 \\
{$[\mathrm{EPy}] \mathrm{Br}+\mathrm{K}_{2} \mathrm{HPO}_{4}$} & 0.0309 & 0.8786 & 0.9946 & 0.08 & 22.7372 & 0.9823 & 0.9950 & 0.16 \\
{$[\mathrm{EPy}] \mathrm{Br}+\mathrm{K}_{2} \mathrm{SO}_{4}$} & 0.0190 & 1.2043 & 0.9984 & 0.07 & 19.0417 & 0.5867 & 0.9978 & 0.11 \\
{$[\mathrm{EPy}] \mathrm{Br}+\mathrm{C}_{4} \mathrm{O}_{6} \mathrm{H}_{4} \mathrm{KNa}$} & 0.0956 & 1.1154 & 0.9828 & 0.85 & 4.5475 & 0.7426 & 0.9868 & 0.06 \\
\hline
\end{tabular}

${ }_{\mathrm{a}} \mathrm{sd}=\left(\sum_{i=1}^{N}\left(100 w_{i, j, \mathrm{cal}}^{\text {top }}-100 w_{i, j \text {,exp }}^{\text {top }}\right)^{2}+\left(100 w_{i, j, \mathrm{cal}}^{\text {bot }}-100 w_{i, j, \text { exp }}^{\text {bot }}\right)^{2} / 2 N\right)^{0.5}$. Where $N$ is the number of tie-lines and $j=1$ and $j=2, \mathrm{sd}_{1}$ and $\mathrm{sd}_{2}$ represent the mass percent standard deviations for $[\mathrm{EPy}] \mathrm{Br}$ and the salt, respectively.

TABLe 9: Parameters of (8) for the [EPy]Br (1) + salt (2) + water (3) ATPS at $T=298.15 \mathrm{~K}$.

\begin{tabular}{|c|c|c|c|c|c|c|}
\hline System & $k_{s}$ & Intercept & $R^{2}$ & $\delta\left(k_{s}\right)^{\mathrm{b}}$ & 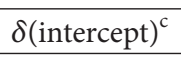 & $100 \mathrm{sd}^{\mathrm{a}}$ \\
\hline$[\mathrm{EPy}] \mathrm{Br}+\mathrm{Na}_{2} \mathrm{HPO}_{4}$ & 2845.9 & -1.8166 & 0.9981 & 88.60 & 0.1512 & 0.09 \\
\hline$[\mathrm{EPy}] \mathrm{Br}+\mathrm{K}_{2} \mathrm{HPO}_{4}$ & 1781.0 & 0.0146 & 0.9999 & 9.71 & 0.0025 & 0.60 \\
\hline$[\mathrm{EPy}] \mathrm{Br}+\mathrm{K}_{2} \mathrm{SO}_{4}$ & 4837.4 & -0.1873 & 0.9963 & 208.70 & 0.0590 & 2.41 \\
\hline$[\mathrm{EPy}] \mathrm{Br}+\mathrm{C}_{4} \mathrm{O}_{6} \mathrm{H}_{4} \mathrm{KNa}$ & 1231.1 & -0.0241 & 0.9996 & 18.37 & 0.0167 & 2.45 \\
\hline
\end{tabular}

${ }_{\mathrm{a}}^{\mathrm{sd}}=\left(\sum_{i=1}^{N}\left(100 w_{i, j, \mathrm{cal}}^{\text {top }}-100 w_{i, j, \exp }^{\text {top }}\right)^{2}+\left(100 w_{i, j, \mathrm{cal}}^{\text {bot }}-100 w_{i, j, \exp }^{\text {bot }}\right)^{2} / 6 N\right)^{0.5}$. Where $N$ is the number of tie-lines and $j$ is the number of components in each phase. $\delta\left(k_{s}\right)^{\mathrm{b}}$ is the standard deviation for the fitting parameters of " $k_{s}$ ". $\delta$ (intercept $)^{\mathrm{c}}$ is the standard deviation of the fitting parameters of the "intercept".

TABLE 10: Parameters of (9) for the [EPy]Br (1) + salt (2) + water (3) ATPS at $T=298.15 \mathrm{~K}$.

\begin{tabular}{|c|c|c|c|c|}
\hline System & $k$ & $\beta$ & $R^{2}$ & $\mathrm{sd}^{\mathrm{a}}$ \\
\hline$[\mathrm{EPy}] \mathrm{Br}+\mathrm{Na}_{2} \mathrm{HPO}_{4}$ & 0.0709 & 0.8535 & 0.9981 & 0.02 \\
\hline$[\mathrm{EPy}] \mathrm{Br}+\mathrm{K}_{2} \mathrm{HPO}_{4}$ & 0.1300 & 0.5822 & 0.9956 & 0.05 \\
\hline$[\mathrm{EPy}] \mathrm{Br}+\mathrm{K}_{2} \mathrm{SO}_{4}$ & 0.0656 & 0.2329 & 0.9984 & 0.03 \\
\hline$[\mathrm{EPy}] \mathrm{Br}+\mathrm{C}_{4} \mathrm{O}_{6} \mathrm{H}_{4} \mathrm{KNa}$ & 0.0926 & 0.8957 & 0.9991 & 0.04 \\
\hline
\end{tabular}

${ }^{a_{\mathrm{sd}}}=\left(\sum_{i=1}^{N}\left(100 w_{i, j, \mathrm{cal}}^{\text {top }}-100 w_{i, j, \mathrm{exp}}^{\text {top }}\right)^{2}+\left(100 w_{i, j, \mathrm{cal}}^{\text {bot }}-100 w_{i, j, \exp }^{\text {bot }}\right)^{2} / 6 N\right)^{0.5}$. Where $N$ is the number of tie-lines and $j$ is the number of components in each phase. 
TABLE 11: Parameters of (10) for the [EPy]Br (1) + salt (2) + water (3) ATPS at $T=298.15 \mathrm{~K}$.

\begin{tabular}{lccccc}
\hline System & $f$ & $g$ & $R^{2}$ & $100 w_{1}$ & $100 w_{2}$ \\
\hline$[\mathrm{EPy}] \mathrm{Br}+\mathrm{Na}_{2} \mathrm{HPO}_{4}$ & 56.8201 & -1.8603 & 0.8777 & 23.77 & 15.06 \\
{$[\mathrm{EPy}] \mathrm{Br}+\mathrm{K}_{2} \mathrm{HPO}_{4}$} & 54.9576 & -4.2020 & 0.9644 & 46.67 & 1.89 \\
{$[\mathrm{EPy}] \mathrm{Br}+\mathrm{K}_{2} \mathrm{SO}_{4}$} & 49.0957 & -5.4588 & 0.9904 & 40.03 & 1.94 \\
{$[\mathrm{EPy}] \mathrm{Br}+\mathrm{C}_{4} \mathrm{O}_{6} \mathrm{H}_{4} \mathrm{KNa}$} & 69.0866 & -2.1286 & 0.9203 & 47.75 & 8.15 \\
\hline
\end{tabular}

${ }^{\mathrm{a}} \mathrm{sd}=\left(\sum_{i=1}^{N}\left(w_{i}^{\mathrm{cal}}-w_{i}^{\exp }\right)^{2} / N\right)^{0.5}$. Where $w_{i}^{\text {exp }}$ is the experimental mass fraction of IL and $w_{i}^{\mathrm{cal}}$ is the corresponding data calculated using (10). The term " $N$ " represents the number of solubility data.

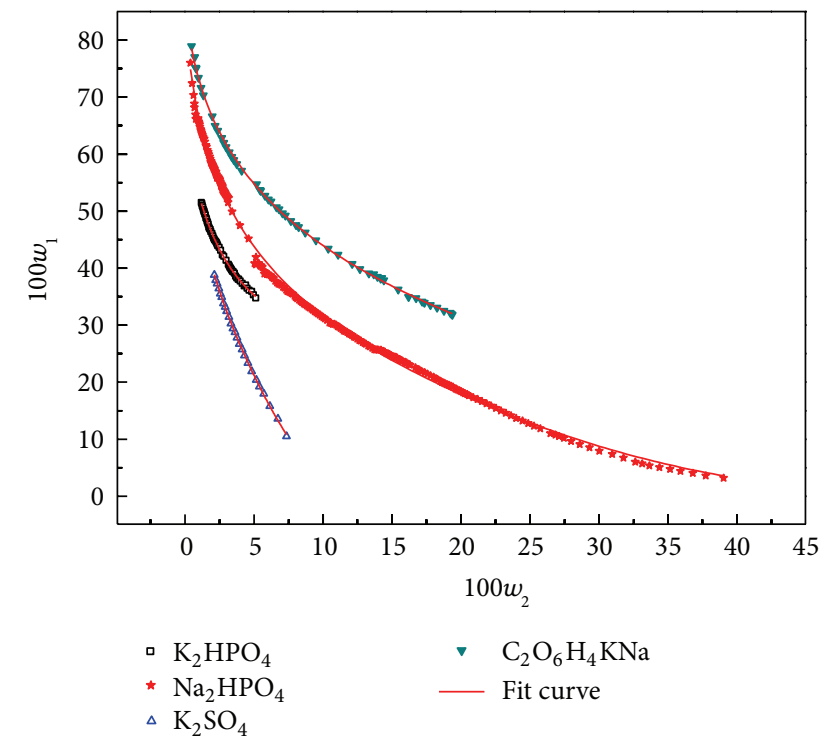

FIgURE 1: Solubility curves of [EPy] Br(1) + salts (2)+water (3) ATPS at $T=298.15 \mathrm{~K}: \star, \mathrm{Na}_{2} \mathrm{HPO}_{4} ; \square, \mathrm{K}_{2} \mathrm{HPO}_{4} ; \triangle, \mathrm{K}_{2} \mathrm{SO}_{4} ; \nabla$, $\mathrm{C}_{4} \mathrm{O}_{6} \mathrm{H}_{4} \mathrm{KNa}$.

derived using the binodal theory [37]. The equation has the following form:

$$
\ln \left(\frac{w_{2}^{t}}{{w_{2}^{b}}^{b}}\right)=\beta+k\left(w_{1}^{b}-w_{1}^{t}\right)
$$

in which $k$ is the salting-out coefficient, and $\beta$ is the constant most closely related to the activity coefficient. The superscripts " $t$ " and " $b$ " represent the IL-rich phase and the salt-rich phase, respectively. Recently, (9) was successfully used to correlate the tie-line data for a polymer-salt ATPS $[45,46]$. The fitting parameters of this equation, the correlation coefficient values $\left(R^{2}\right)$, and the standard deviations (sd) are provided in Table 10.

The standard deviations in Tables $8-10$ are small, indicating that (6)-(9) are appropriate for correlating the tieline data of the ATPSs especially the Setschenow-type equation. For more details about the relationship between the Setschenow-type behavior and the phase diagrams, the Setschenow-type plots of the tie-line data for the investigated systems are also shown in Figure 4 . The Setschenow-type plots with data from Table 9 indicate that the larger the slope, the larger the $k_{s}$. When combining with Figure 1, the

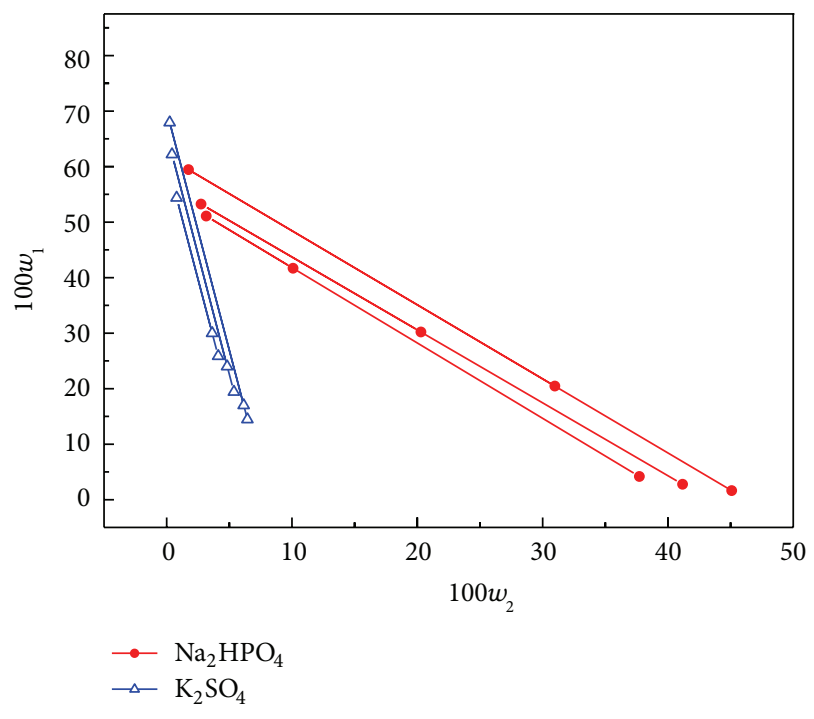

Figure 2: Tie-lines of [EPy]Br (1) + salts (2) + water (3) ATPS at $T=298.15 \mathrm{~K}: \bullet, \mathrm{Na}_{2} \mathrm{HPO}_{4} ; \triangle, \mathrm{K}_{2} \mathrm{SO}_{4}$.

larger the $k_{s}$, the higher salting-out ability. This behavior is in agreement with the reported results for other ATPSs [47].

3.4. Calculation of the Plait Point. Plait points are points on the solubility curves where the length of tie-lines shrank to almost zero, indicating that the two liquid phases become identical [48]. The plait points data for the investigated ATPSs in this study were calculated via the following linear equation:

$$
w_{1}=f+g w_{2}
$$

in which $f$ and $g$ are the fitting parameters. For the four systems, the estimated values of the plait points along with the fitting parameters obtained from (10) and the corresponding correlation coefficients are given in Table 11.

3.5. Effect of Salts on Solubility Curves and Tie-Lines. Figure 1 presents the effect of different salts on the solubility curves. It is clear that different salts possess two-phase areas of different sizes. In this study, $\mathrm{K}_{2} \mathrm{SO}_{4}$ owns the largest area of two phase; therefore, the phase-separation ability of $\mathrm{K}_{2} \mathrm{SO}_{4}$ precedes the other three.

Considering that the salts $\mathrm{Na}_{2} \mathrm{HPO}_{4}$ and $\mathrm{K}_{2} \mathrm{HPO}_{4}$ share a common anion $\mathrm{HPO}_{4}{ }^{2-}$ but contain different cations, one can conclude that the salting-out ability of $\mathrm{K}^{+}$is higher than 


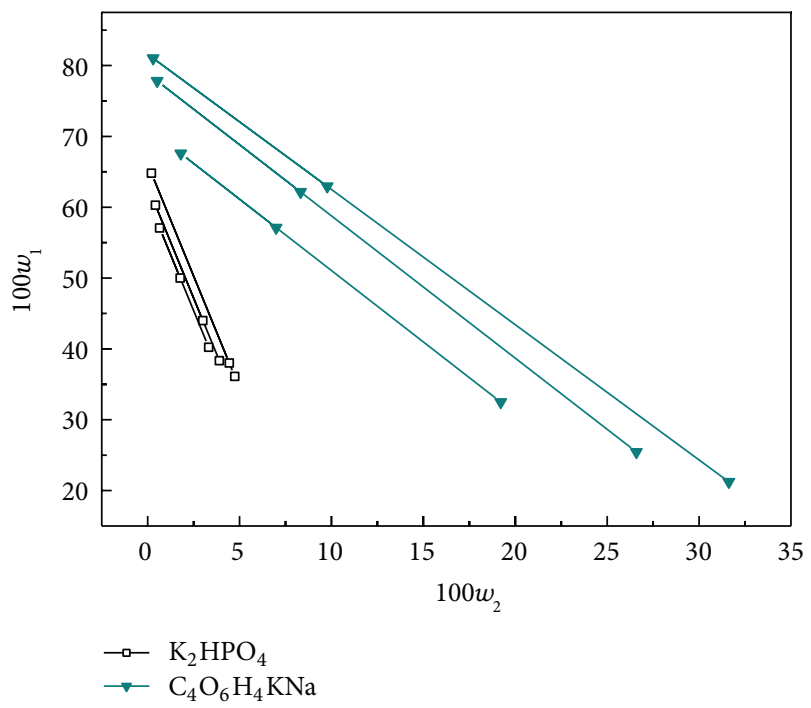

FIgure 3: Tie-lines of [EPy] Br (1) + salts (2) + water (3) ATPS at $T=298.15 \mathrm{~K}: \square, \mathrm{K}_{2} \mathrm{HPO}_{4} ; \boldsymbol{\nabla}, \mathrm{C}_{4} \mathrm{O}_{6} \mathrm{H}_{4} \mathrm{KNa}$.

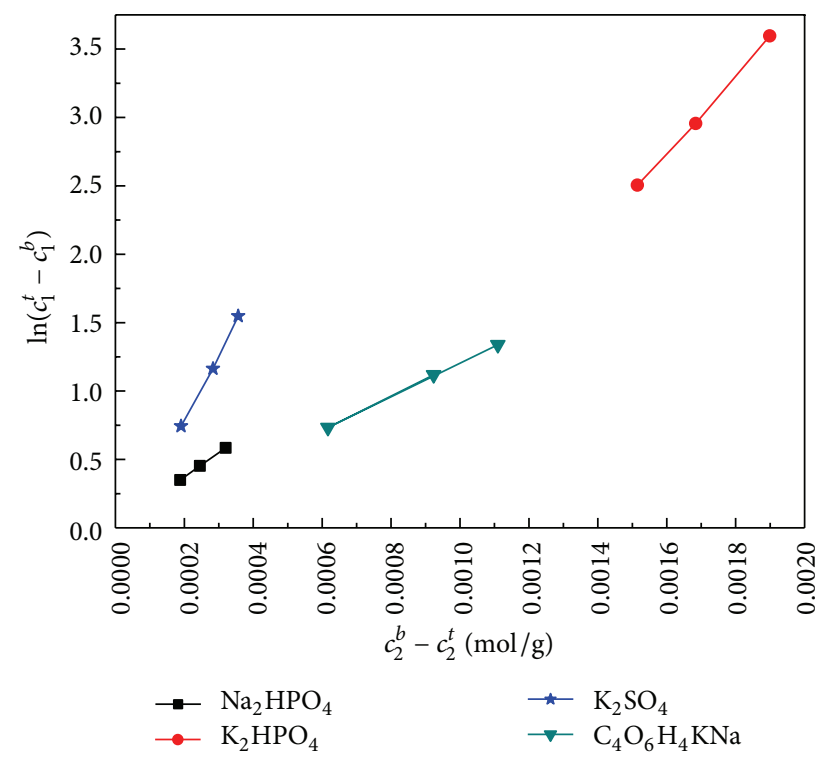

Figure 4: Tie-lines of [EPy]Br (1) + salts(2) + water(3) ATPS fitted by Setschenow-type equation at $T=298.15 \mathrm{~K}: \mathbf{\square}, \mathrm{Na}_{2} \mathrm{HPO}_{4}$; $\bullet$, $\mathrm{K}_{2} \mathrm{HPO}_{4} ; \star, \mathrm{K}_{2} \mathrm{SO}_{4} ; \boldsymbol{\nabla}, \mathrm{C}_{4} \mathrm{O}_{6} \mathrm{H}_{4} \mathrm{KNa}$.

that $\mathrm{Na}^{+}$at a constant temperature, which is contrary to what Chen and Wang [49] obtained from their research. This may be due to the relatively large radius of $\mathrm{HPO}_{4}{ }^{2-}$. Also, the $\mathrm{K}_{2} \mathrm{HPO}_{4}$ and $\mathrm{K}_{2} \mathrm{SO}_{4}$ share a common cation $\mathrm{K}^{+}$, but the $\mathrm{EEV}$ for $\mathrm{K}_{2} \mathrm{SO}_{4}$ is higher than that of $\mathrm{K}_{2} \mathrm{HPO}_{4}$; therefore, the salting-out ability of $\mathrm{SO}_{4}{ }^{2-}$ is higher than that of $\mathrm{HPO}_{4}{ }^{2-}$ at the same temperature. When it comes to $\mathrm{C}_{4} \mathrm{O}_{6} \mathrm{H}_{4} \mathrm{KNa}$, which owns both $\mathrm{K}^{+}$and $\mathrm{Na}^{+}$, it might be the organic ion $\mathrm{C}_{4} \mathrm{O}_{6} \mathrm{H}_{4}{ }^{2-}$ that brings about the weakest salting-out ability.

Figures 2 and 3 present the effect of different salts on the phase compositions, from which it can be informed that the slopes of tie-lines differ greatly towards different salt types.
The slopes of tie-lines for ATPS containing $\mathrm{K}_{2} \mathrm{SO}_{4}$ are of the largest value, illustrating that $\mathrm{K}_{2} \mathrm{SO}_{4}$ hydrates the most water, thus decreasing the amount of water available to hydrate [EPy]Br.

\section{Conclusions}

The liquid-liquid equilibrium data have been determined for [EPy] Br + salt $\left(\mathrm{Na}_{2} \mathrm{HPO}_{4}, \mathrm{~K}_{2} \mathrm{HPO}_{4}, \mathrm{~K}_{2} \mathrm{SO}_{4}\right.$ and $\mathrm{C}_{4} \mathrm{O}_{6} \mathrm{H}_{4} \mathrm{KNa}$ ) ATPSs at $T=298.15 \mathrm{~K}$. The effect of salt on solubility curves as well as tie-lines was studied. The volume (EEV) values obtained from the binodal model together with the phase diagram indicated the order of phase separation abilities of the four salts. The Merchuk equation and two other equations were used to correlate the solubility data and the Othmer-Tobias, Bancroft, and Setschenow-type equations and a two-parameter equation were used to correlate the tie-line data. The results indicate that the calculation method and the corresponding tie-line data are reliable. At fixed temperatures, the salting-out ability of $\mathrm{K}^{+}$is higher than that of $\mathrm{Na}^{+}$, and that of anions follows $\mathrm{SO}_{4}{ }^{2-}>\mathrm{HPO}_{4}{ }^{2-}>\mathrm{C}_{4} \mathrm{O}_{6} \mathrm{H}_{4}{ }^{2-}$.

\section{List of Symbols}

$N$ :

$N$ :

T:

TLL:

$S:$

$w:$

$k_{s}, k_{\mathrm{IL}}:$

$\beta$ :

$V_{213}^{*}$ :

$f_{213}$ :

$M:$

$a, b, c, d, a_{1}, b_{1}, a_{2}, b_{2}, k_{1}, n, k_{2}, r, k$ : Fitting parameters

$R^{2}$ :

sd:

Number of solubility data Number of tie-lines

Temperature (K)

Tie-line length

Slope of the tie-line

Mass fraction

Salting-out coefficient Interaction parameter

Scaled EEV of salt

Volume fraction

Molar mass

Correlation coefficient

Standard deviation.

\section{Super/Subscript}

b: Bottom phase

$t$ : Top phase

cal: Calculated value

exp: Experimental value

1: $\quad$ [EPy]Br

2: $\quad$ Salt

3: Water.

\section{Conflict of Interests}

None of the authors for this paper have a direct financial relation with the commercial identity mentioned in this paper. 


\section{Acknowledgments}

This work was sponsored by the Research and Development Project of Science and Technology of Shaanxi Province (no. 2013JQ2019), the Fundamental Research Funds for the Central Universities (no. 2013G2291015, 2013G1291071, and 2013G1502038) and the National Training Projects of the University Students' Innovation and Entrepreneurship program (no. 201310710057).

\section{References}

[1] P. A. Albertsson, Partition of Cell Particles and Macromolec, John Wiley \& Sons, 3rd edition, 1986.

[2] W. Riedl and T. Raiser, "Membrane-supported extraction of biomolecules with aqueous two-phase systems," Desalination, vol. 224, no. 1-3, pp. 160-167, 2008.

[3] F. Luechau, T. C. Ling, and A. Lyddiatt, "Partition of plasmid DNA in polymer-salt aqueous two-phase systems," Separation and Purification Technology, vol. 66, no. 2, pp. 397-404, 2009.

[4] S. M. Baxter, P. R. Sperry, and Z. Fu, "Partitioning of polymer and inorganic colloids in two-phase aqueous polymer systems," Langmuir, vol. 13, no. 15, pp. 3948-3952, 1997.

[5] A. Boaglio, G. Bassani, G. Picó, and B. Nerli, "Features of the milk whey protein partitioning in polyethyleneglycol-sodium citrate aqueous two-phase systems with the goal of isolating human alpha-1 antitrypsin expressed in bovine milk," Journal of Chromatography B, vol. 837, no. 1-2, pp. 18-23, 2006.

[6] P. Wasserscheid and T. Welton, Ionic Liquids in Synthesis, WileyVCH, 2nd edition, 2008.

[7] D. R. MacFarlane, P. Meakin, J. Sun, N. Amini, and M. Forsyth, "Pyrrolidinium imides: a new family of molten salts and conductive plastic crystal phases," Journal of Physical Chemistry B, vol. 103, no. 20, pp. 4164-4170, 1999.

[8] C. Y. He, S. H. Li, H. W. Liu, K. Li, and F. Liu, "Extraction of testosterone and epitestosterone in human urine using aqueous two-phase systems of ionic liquid and salt," Journal of Chromatography A, vol. 1082, no. 2, pp. 143-149, 2005.

[9] R. Lertlapwasin, N. Bhawawet, A. Imyim, and S. Fuangswasdi, "Ionic liquid extraction of heavy metal ions by 2aminothiophenol in 1-butyl-3-methylimidazolium hexafluorophosphate and their association constants," Separation and Purification Technology, vol. 72, no. 1, pp. 70-76, 2010.

[10] B. Jiang, Z.-G. Li, J.-Y. Dai, D.-J. Zhang, and Z.-L. Xiu, "Aqueous two-phase extraction of 2, 3-butanediol from fermentation broths using an ethanol/phosphate system," Process Biochemistry, vol. 44, no. 1, pp. 112-117, 2009.

[11] Y. Y. Jiang, H. S. Xia, C. Guo, I. Mahmood, and H. Liu, "Enzymatic hydrolysis of penicillin in mixed ionic liquids/water twophase system," Biotechnology Progress, vol. 23, no. 4, pp. 829835, 2007.

[12] C. X. Li, J. Han, Y. Wang, Y. S. Yan, X. H. Xu, and J. M. Pan, "Extraction and mechanism investigation of trace roxithromycin in real water samples by use of ionic liquid-salt aqueous two-phase system," Analytica Chimica Acta, vol. 653, no. 2, pp. 178-183, 2009.

[13] B. Wu, Y. M. Zhang, and H. P. Wang, "Aqueous biphasic systems of hydrophilic ionic liquids + sucrose for separation," Journal of Chemical \& Engineering Data, vol. 53, no. 4, pp. 983-985, 2008.

[14] B. Wu, Y. M. Zhang, and H. P. Wang, "Phase behavior for ternary systems composed of ionic liquid + saccharides + water," Journal of Physical Chemistry B, vol. 112, no. 20, pp. 6426-6429, 2008.
[15] Y. C. Pei, J. J. Wang, L. Liu, K. Wu, and Y. Zhao, "Liquid-liquid equilibria of aqueous biphasic systems containing selected imidazolium ionic liquids and salts," Journal of Chemical \& Engineering Data, vol. 52, no. 5, pp. 2026-2031, 2007.

[16] M. T. Zafarani-Moattar and S. Hamzehzadeh, "Liquid-liquid equilibria of aqueous two-phase systems containing 1-butyl3-methylimidazolium bromide and potassium phosphate or dipotassium hydrogen phosphate at $298.15 \mathrm{~K}$," Journal of Chemical \& Engineering Data, vol. 52, no. 5, pp. 1686-1692, 2007.

[17] M. T. Zafarani-Moattar and S. Hamzehzadeh, "Phase diagrams for the aqueous two-phase ternary system containing the ionic liquid 1-butyl-3-methylimidazolium bromide and tripotassium citrate at $\mathrm{T}=(278.15,298.15$, and 318.15$) \mathrm{K}$," Journal of Chemical \& Engineering Data, vol. 54, no. 3, pp. 833-841, 2009.

[18] T. Mourao, A. F. M. Claudio, I. Boal-Palheiros, M. G. Freire, and J. A. P. Coutinho, "Evaluation of the impact of phosphate salts on the formation of ionic-liquid-based aqueous biphasic systems," The Journal of Chemical Thermodynamics, vol. 54, pp. 398-405, 2012.

[19] C. X. Li, J. Han, Y. Wang et al., "Phase behavior for the aqueous two-phase systems containing the ionic liquid 1-butyl-3methylimidazolium tetrafluoroborate and kosmotropic salts," Journal of Chemical \& Engineering Data, vol. 55, no. 3, pp. 10871092, 2010.

[20] J. Han, C. L. Yu, Y. Wang et al., "Liquid-liquid equilibria of ionic liquid 1-butyl-3-methylimidazolium tetrafluoroborate and sodium citrate/tartrate/acetate aqueous two-phase systems at 298.15 K: experiment and correlation," Fluid Phase Equilibria, vol. 295, no. 1, pp. 98-103, 2010.

[21] Y. Wang, X. H. Xu, Y. S. Yan, J. Han, and Z. L. Zhang, "Phase behavior for the [Bmim]BF4 aqueous two-phase systems containing ammonium sulfate/sodium carbonate salts at different temperatures: experimental and correlation," Thermochimica Acta, vol. 501, no. 1-2, pp. 112-118, 2010.

[22] J. Han, R. Pan, X. Q. Xie et al., "Liquid-liquid equilibria of ionic liquid 1-butyl-3-methylimidazolium tetrafluoroborate + sodium and ammonium citrate aqueous two-phase systems at (298.15, 308.15, and 323.15) K," Journal of Chemical \& Engineering Data, vol. 55, no. 9, pp. 3749-3754, 2010.

[23] S. I. Abu-Eishah and A. M. Dowaidar, "Liquid-liquid equilibrium of ternary systems of cyclohexane + (benzene, + toluene, + ethylbenzene, or + o-xylene) + 4-methyl-N-butyl pyridinium tetrafluoroborate ionic liquid at $303.15 \mathrm{~K}$," Journal of Chemical \& Engineering Data, vol. 53, no. 8, pp. 1708-1712, 2008.

[24] N. J. Bridges, K. E. Gutowski, and R. D. Rogers, "Investigation of aqueous biphasic systems formed from solutions of chaotropic salts with kosmotropic salts (salt-salt ABS)," Green Chemistry, vol. 9, no. 2, pp. 177-183, 2007.

[25] F. J. Deive, M. A. Rivas, and A. Rodriguez, "Sodium carbonate as phase promoter in aqueous solutions of imidazolium and pyridinium ionic liquids," The Journal of Chemical Thermodynamics, vol. 43, no. 8, pp. 1153-1158, 2011.

[26] S. P. M. Ventura, S. G. Sousa, L. S. Serafim, Á. S. Lima, M. G. Freire, and J. A. P. Coutinho, "Ionic liquid based aqueous biphasic systems with controlled $\mathrm{pH}$ : the ionic liquid cation effect," Journal of Chemical \& Engineering Data, vol. 56, no. 11, pp. 4253-4260, 2011.

[27] J. Na, Q. H. Yang, X. C. Dong, and S. N. Zhao, "Extraction and separation of rutin in ionic liquid aqueous two-phase system," Yunnan Chemical Technology, vol. 35, no. 3, pp. 36-41, 2008.

[28] D.-H. Zhao, Y.-B. Zeng, L. Li et al., "Determination of chloramphenicol in eggs using an aqueous two phase systems of 
pyridine ionic liquid and salt," Chinese Journal of Analytical Chemistry, vol. 37, no. 3, pp. 445-448, 2009.

[29] J. Chen, S. K. Spear, J. G. Huddleston, J. D. Holbrey, R. P. Swatloski, and R. D. Rogers, "Application of poly(ethylene glycol)-based aqueous biphasic systems as reaction and reactive extraction media," Industrial and Engineering Chemistry Research, vol. 43, no. 17, pp. 5358-5364, 2004.

[30] J. C. Merchuk, B. A. Andrews, and J. A. Asenjo, "Aqueous twophase systems for protein separation studies on phase inversion," Journal of Chromatography B, vol. 711, no. 1-2, pp. 285-293, 1998.

[31] L. A. Ferreira and J. A. Teixeira, "Salt effect on the aqueous twophase system PEG 8000-sodium sulfate," Journal of Chemical \& Engineering Data, vol. 56, no. 1, pp. 133-137, 2011.

[32] M. Foroutan, "Liquid-liquid equilibria of aqueous two-phase poly(vinylpyrrolidone) and $\mathrm{K}_{2} \mathrm{HPO}_{4} / \mathrm{KH}_{2} \mathrm{PO}_{4}$ buffer: effects of $\mathrm{pH}$ and temperature," Journal of Chemical \& Engineering Data, vol. 52, no. 3, pp. 859-862, 2007.

[33] M. Hu, Q. Zhai, Z. Liu, and S. Xia, "Liquid-liquid and solidliquid equilibrium of the ternary system ethanol + cesium sulfate + water at $(10,30 \text {, and } 50)^{\circ} \mathrm{C}$," Journal of Chemical o Engineering Data, vol. 48, no. 6, pp. 1561-1564, 2003.

[34] H. Shekaari, R. Sadeghi, and S. A. Jafari, "Liquid-liquid equilibria for aliphatic alcohols + dipotassium oxalate + water," Journal of Chemical \& Engineering Data, vol. 55, no. 11, pp. 4586-4591, 2010.

[35] Y. Wang, Y. S. Yan, and S. P. Hu, "Phase diagrams of ammonium sulfate + ethanol/1-propanol/2-propanol + water aqueous twophase systems at $298.15 \mathrm{~K}$ and correlation," Journal of Chemical \& Engineering Data, vol. 55, no. 2, pp. 876-881, 2010.

[36] X. Q. Xie, J. Han, Y. Wang, Y. S. Yan, G. W. Yin, and W. X. Guan, "Measurement and correlation of the phase diagram data for $\mathrm{PPG}_{400}+\left(\mathrm{K}_{3} \mathrm{PO}_{4}, \mathrm{~K}_{2} \mathrm{CO}_{3}\right.$, and $\left.\mathrm{K}_{2} \mathrm{HPO}_{4}\right)+\mathrm{H}_{2} \mathrm{O}$ aqueous two-phase systems at $\mathrm{T}=298.15 \mathrm{~K}$," Journal of Chemical \& Engineering Data, vol. 55, no. 11, pp. 4741-4745, 2010.

[37] Y. Guan, T. H. Lilley, and T. E. Treffry, "A new excluded volume theory and its application to the coexistence curves of aqueous polymer two-phase systems," Macromolecules, vol. 26, no. 15, pp. 3971-3979, 1993.

[38] I. Regupathi, S. Murugesan, R. Govindarajan, S. P. Amaresh, and M. Thanapalan, "Liquid-liquid equilibrium of poly(ethylene glycol) $6000+$ triammonium citrate + water systems at different temperatures," Journal of Chemical \& Engineering Data, vol. 54, no. 3, pp. 1094-1097, 2009.

[39] J. G. Huddleston, H. D. Willauer, and R. D. Rogers, "Phase diagram data for several PEG + salt aqueous biphasic systems at $25^{\circ}$ C, Journal of Chemical \& Engineering Data, vol. 48, no. 5, pp. 1230-1236, 2003.

[40] M. T. Zafarani-Moattar and S. Hamzehzadeh, "Liquid-liquid equilibria of aqueous two-phase systems containing polyethylene glycol and sodium succinate or sodium formate," Calphad, vol. 29, no. 1, pp. 1-6, 2005.

[41] R. D. Rogers, A. H. Bond, C. B. Bauer, J. Zhang, and S. T. Griffin, "Metal ion separations in polyethylene glycol-based aqueous biphasic systems: correlation of partitioning behavior with available thermodynamic hydration data," Journal of Chromatography B, vol. 680, no. 1-2, pp. 221-229, 1996.

[42] D. F. Othmer and P. E. Tobias, "Liquid-liquid extraction datatoluene and acetaldehyde systems," Industrial \& Engineering Chemistry Research, vol. 34, no. 6, pp. 690-692, 1942.

[43] P. G. González-Tello, F. Camacho, G. Blázquez, and F. J. Alarc, "Liquid-liquid equilibrium in the system poly(ethylene glycol)
$+\mathrm{MgSO}_{4}+\mathrm{H}_{2} \mathrm{O}$ at $298 \mathrm{~K}$, Journal of Chemical \& Engineering Data, vol. 41, no. 6, pp. 1333-1336, 1996.

[44] M. J. Hey, D. P. Jackson, and H. Yan, "The salting-out effect and phase separation in aqueous solutions of electrolytes and poly(ethylene glycol)," Polymer, vol. 46, no. 8, pp. 2567-2572, 2005.

[45] M. T. Zafarani-Moattar and S. Hamzehzadeh, "Liquid-liquid equilibria of aqueous two-phase systems containing polyethylene glycol and sodium succinate or sodium formate," Calphad, vol. 29, no. 1, pp. 1-6, 2005.

[46] M. T. Zafarani-Moattar and P. Seifi-Aghjekohal, "Liquid-liquid equilibria of aqueous two-phase systems containing polyvinylpyrrolidone and tripotassium phosphate or dipotassium hydrogen phosphate: experiment and correlation," Calphad, vol. 31, no. 4, pp. 553-559, 2007.

[47] X. Q. Xie, Y. S. Yan, J. Han, Y. Wang, G. W. Yin, and W. S. Guan, "Liquid-liquid equilibrium of aqueous two-phase systems of $\mathrm{PPG}_{400}$ and biodegradable salts at temperatures of (298.15, 308.15, and 318.15) K," Journal of Chemical \& Engineering Data, vol. 55, no. 8, pp. 2857-2861, 2010.

[48] R. M. de Oliveira, J. S. dos Reis Coimbra, K. R. Francisco, L. A. Minim, L. H. M. Da Silva, and E. E. G. Rojas, "Equilibrium data of the biphasic system poly(ethylene oxide) $4000+$ copper sulfate + water at $(5,10,35 \text {, and } 45)^{\circ} \mathrm{C}$, Journal of Chemical o Engineering Data, vol. 53, no. 7, pp. 1571-1573, 2008.

[49] J. Chen and Q. Wang, "Combustion characteristics and dynamic modeling of micro engine," Journal of Jiangsu University, vol. 31, no. 3, pp. 304-308, 2010. 

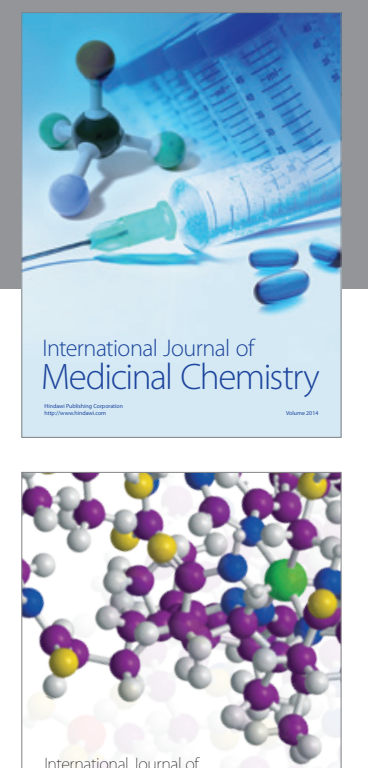

\section{Carbohydrate} Chemistry

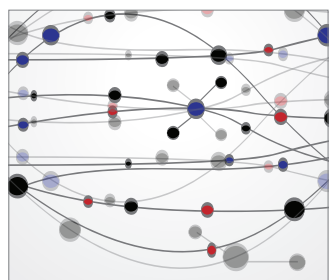

The Scientific World Journal
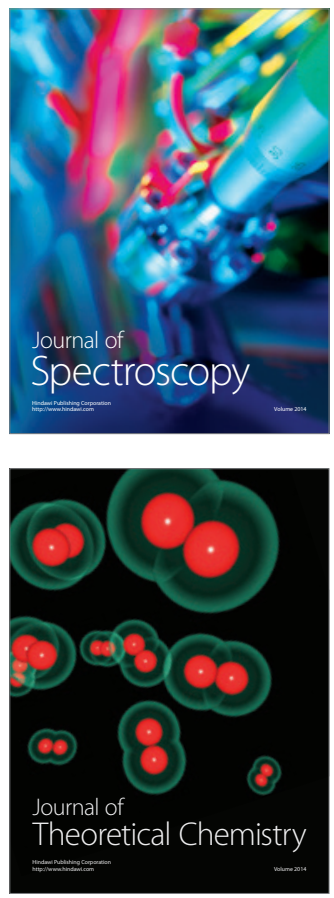
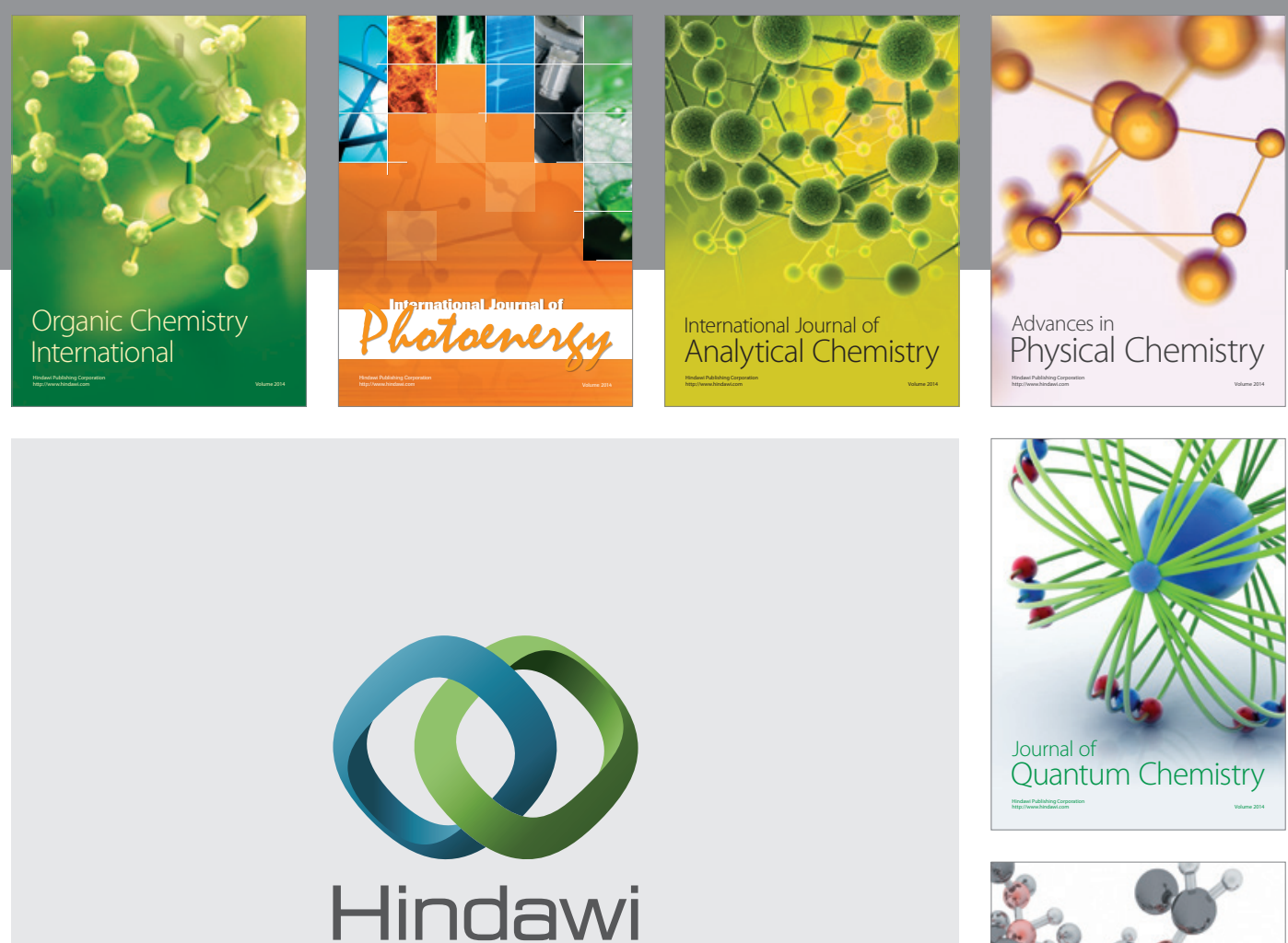

Submit your manuscripts at

http://www.hindawi.com

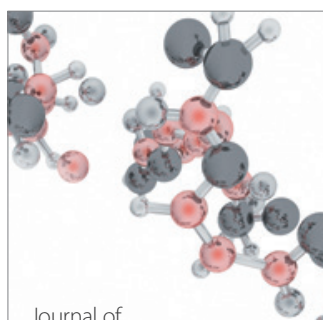

Analytical Methods

in Chemistry

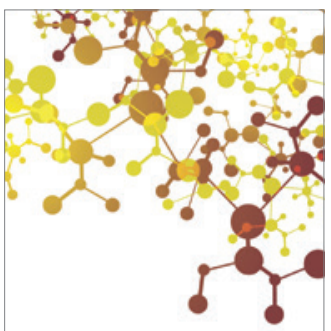

Journal of

Applied Chemistry

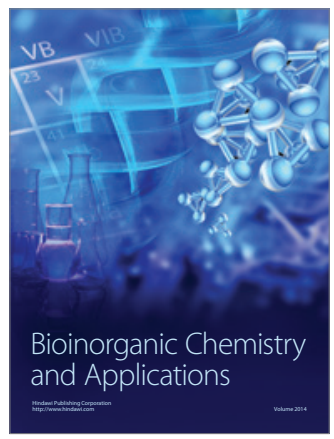

Inorganic Chemistry
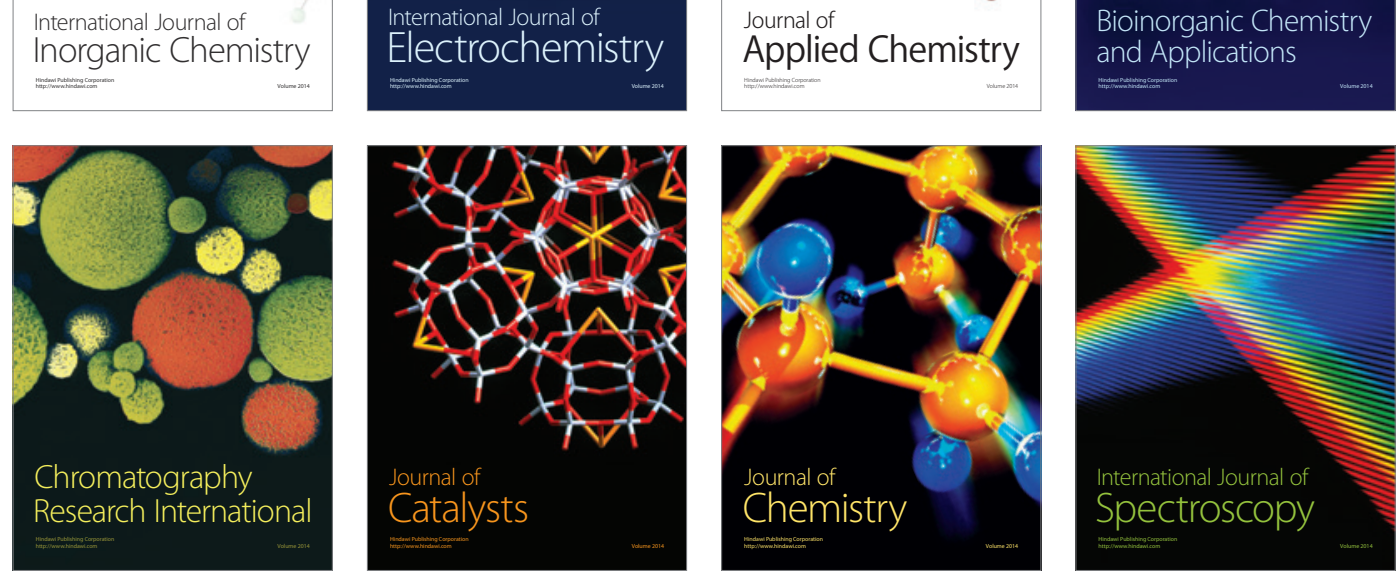